\section{Challenges Facing Women Micro Entrepreneurs in Dar Es Salaam, Tanzania}

\author{
Dr Nelson Jagero (Corresponding Author) \\ Senior Lecturer \\ Kampala International University Dar es Salaam College, School of Post Graduate and \\ Research \\ E mail; jagero66@yahoo.com
}

Ikandilo Kushoka

Lecturer

Institute of Accountancy Arusha.

PhD Scholar of Business Management at Kampala International University

Dar es Salaam College

Email: ikush@yahoo.com

Received: September 15, 2011 Accepted: October 5, 2011 Published: October 18, 2011

Doi:10.5296/ijhrs.v1i2.1023ＵRL: http://dx.doi.org/10.5296/ijhrs.v1i2.1023

\begin{abstract}
This study analyzes the challenges facing women micro entrepreneurs in Ilala Municipal Dar es Salaam. The author's choice of this topic is derived from the public outcry concerning the treatment of micro entrepreneurs by the municipal officials in Ilala, Dar es Salaam.

The author interviewed 120 women micro entrepreneurs in Ilala Municipality to answer the research question: What are the challenges facing Women Micro Entrepreneurs in Ilala Municipality emanating from an ongoing campaign to "Clean the City".

Results indicate that major challenges facing women micro entrepreneurs are poor infrastructure, lack of business premise, decline in business and lack of prime space.
\end{abstract}

Key words: Entrepreneurs, Micro entrepreneurs, Entrepreneurship, Women. 


\section{INTRODUCTION}

Women are constrained by education/training, business experience, discriminations, socialization/networking and unwillingness to take risk (Nchimbi, 2002). Also the overall negative attitudes towards the business owned by women- particularly by men, and inadequate and affordable business premises also limit the overall performance of female owned enterprises. On sources of funds for starting and running business, the insufficient internally generated liquidity is therefore one of the factors which are frequently cited as the causes of micro entrepreneurs business failure (Chijoriga and Cassimon, 1999).

In Ilala, the cultural environment of coast regions makes it more difficult for women to start and run enterprises due to the expectations and demands of their traditional reproductive roles (Olomi, 2003). The negative attitude and belief about women's traditional role have some significant impact on women entrepreneurs as indicated below: (1) Not being able to access appropriate resources (2) Being especially vulnerable to harassment from male officials and business men (3) Lack of adequate education (4) Limited or no experience of formal employment and business (5) limited network especially business related networks.

There exists a market failure discriminating against women's possibility to become entrepreneurs and their possibility to become successful entrepreneurs. This market failure needs to be addressed so that the economic potential of this group can be fully utilized. While without a doubt the economic impact of women is substantial, we still lack a reliable picture describing in detail that specifies such impact. Recent efforts initiated by the Organization for Economic Cooperation and Development - OECD (2004) are responses to this lack of knowledge and have focused the attention of researchers on this important topic.

Women in entrepreneurship has also been largely neglected both in society in general and in the social sciences. Moreover, fewer women participation rates in entrepreneurship than men but they also have generally peculiarity of choosing to start and manage firms in different industries than men tend to do. The industries (primarily retail, education and other service industries) chosen by women are often perceived as being less important to economic development and growth. Furthermore, research, policies and programmes tend to be "gender biased" and too often do not take into account the specific needs of women entrepreneurs and would-be women entrepreneurs. As a consequence of equal opportunity between men and women from the perspective of entrepreneurship is still not a reality.

Objective: To analyze the challenges facing women micro entrepreneurs emanating from government's on going campaign to clean the city. 


\section{LITERATURE REVIEW}

Different studies have revealed that enterprises owned by women experience the same challenges as those owned by men; however certain characteristics are typical for many women-owned firms. These characteristics include: small size, limited prospects for profitability and failure to provide collateral for obtaining loans (Coleman, 2002).

Women's entry in business in Tanzania is a recent phenomenon, mainly a result of the economic crisises and restructuring programmes which has led to drastic decline in real wages as well as formal employment opportunities (Rutashobya, 1995). Probably as a result of the recent nature of women's involvement in business, much of the research that has been carried out was aimed at making general description of women in the sector along with a cross-section of the barriers that they face. Indeed, one of the limitations of the existing entrepreneurship literature in Africa and Tanzania in particular, is its treatment of women entrepreneurs as a homogeneous group (Nchimbi, 1999). In reality, women entrepreneurs differ in many ways in terms of age, religion, ethnicity, wealth, education, literacy, marital status, social status, experience and socio-economic position. They also differ in terms of their motivation to start and develop businesses. These differences, according to Koda and Omari (1991), are responsible for a considerable variation in the nature, scope and magnitude of women's entrepreneurial activities.

Entrepreneurial behaviour is a function of environmental factors including cultural and traditional values and prejudices. In Tanzania, women have been socialized to be subordinates to men. In many traditions, women are raised to see their ultimate role in life as that of wives and mothers. They are socialized to be non-argumentative, passive and easy to accept defeat (Rutashobya, 1995). This may have significantly affected their self-confidence, achievement-motivation and even their willingness to take risk, qualities that are closely linked to success in business.

There is some empirical evidence in support of the notion that women have less of these qualities. In recent studies, Nchimbi (2002) found women entrepreneurs to be more internally oriented suggesting lack of confidence. In addition, women were found to have lower need for achievement compared to men. There is a wide range of reasons as to why people choose to engage in business.

According to Olomi (2001), the pressure for women to start business activities to meet basic needs or supplement income was a prominent motive especially following the economic crises of the 1970s and early 1980s and the subsequent structural adjustment programmes. These programmes led to erosion of purchasing power of salaried workers and limited job openings. The impact has been felt most by women, who have a greater burden of enabling the family to cope. Olomi and Sinyamule (2007) noted that in some cases, women have become the main breadwinners. Another explanation for the increased prominence of this motive is that the number of single mothers has been increasing, and many of these do not have any means of earning their livelihood other than self-employment. Women have reported that they get respected and trusted by husbands and others because they are self employed. Some women have noted that when they are generating income from business activity their husband cannot harass them, because they can take care of the family without the husbands' financial support 
(Lwihula, 1999). This however does not apply to all women. It has been found that in some cases, economic independence and success of women are seen as a threat to the control of women by men (Lutege and Wagner, 2002).

It therefore appears that women's concentration in particular activities is not accidental. Women appear to be quite pragmatic in deciding on the type of activities to engage in. Women start businesses alone or in association with other women, friends or family members. Research has revealed that women's perception of business differ from that of men. While men treat their businesses as economic entities women's businesses become integrated with other demanding areas of life (Cheston and Kuhn, 2008). As result women entrepreneurs have been found to perceive their business success using criteria other than the traditional economic ones. Whereas male entrepreneurs use economic criteria to assess their business success, women put more emphasis on family and employee's related measures (Cheston and Kuhn, 2008).

\section{METHODOLOGY}

\section{Population and Sample}

In this research, the population of interest included all women micro entrepreneurs and municipal officials in Ilala. Women micro entrepreneurs are about 300,000 and Municipal Officials are about 50.

Micro entrepreneurs: - The sample of the study was categorized into two major groups. The first category consisted of hundred and twenty (120) women micro entrepreneurs. Women micro entrepreneurs were involved in this study because of their direct involvement in trade and they are the group most affected by the implementation of reallocation policies.

\section{Sampling Procedures}

In this study, the researcher used clustering sampling to obtain micro entrepreneurs for the following reasons. First, micro entrepreneurs are scattered over a wide area in Ilala municipality. Secondly, a list of micro entrepreneurs is not readily available for the researcher to refer to. Finally, micro entrepreneurs are at different levels of age and education. Purposive sampling was employed to obtain municipal officials.

\section{Data analysis}

Data processing involved the use of a computer package known as "Statistical Package for Social Scientists" (SPSS ver. 12). Data was extracted from filled summary sheets and processed. The major computations involved, included: totals, means, averages, distributions, proportions and statistical Z-sample values for the purpose of testing whether they meet the objectives.

\section{FINDINGS}

The second research question intended to analyze the challenges that women micro entrepreneurs in Ilala Municipality faced. In addition to lack of education they also have other 
challenges which are of financial and infrastructure nature (22.2 per cent). Specifically the study has revealed that 19.4 percent of the respondents faced the challenge of loss of capital encountered when either they were frequently being moved by city authority or while they were being harassed by municipal policemen. Related to this they also faced a decline in business activities and lack of space as shown in table 1 below.

Table 1: Challenges faced by women micro entrepreneurs

\begin{tabular}{ll}
\hline CHALLENGES & PERCENTAGE (\%) \\
\hline Loss of capital & 19.4 \\
Decline in business & 18.0 \\
Lack of Prime Space & 19.9 \\
Poor infrastructure & 22.2 \\
Lack of General Space & 15.0 \\
Corruption & 5.5 \\
Total & 100 \\
\hline
\end{tabular}

\section{Source: Field survey, 2010}

The challenge for space being faced by women micro entrepreneurs has two aspects: lack of the prime space (city centre) and general lack of space in any area of the city. Nearly 19.9 percent of respondents in the current study faced shortage of prime space for operations. Another 15 percent of respondents noted that they generally faced the lack of space for doing business. Another challenge facing women micro entrepreneurs was of infrastructure nature affecting 22.2 percent of them. Poor infrastructure was a challenge cited by respondents, including during the rainy seasons when women micro entrepreneurs had little protection from rain or choking sun during hot seasons. Corruption affected 5.5 percent of women micro entrepreneurs. (Harassment by city authority- to solicit bribe, being shifted irregularly by officials now and then in order to get bribe - those who can not pay are shifted).

These findings are in line with those obtained by Kombe (2005). One form of reactions is characterized by skirmishes and massive clashes between the police and micro traders (Machingas),since machingas and women micro entrepreneurs do work side by side, the clashes often resulting into loss of millions of worth business owned by micro business traders; including women micro entrepreneurs.

It was obtained that shortage of prime and general spaces were contributed by Municipal authorities. During the interview with Municipal officials about 70 per cent suggested that reallocation of trading sites was offered only to those traders who were having large capital. The findings from this study are in line with those obtained by Lyons and Msoka 
(2007) in their study on micro-trading in Tanzania. According to Lyons and Msoka (2007), it is difficult to estimate directly the total numbers of micro traders affected by the space reallocation policy. What is clear is that a large number of micro traders have been involved. The study exemplified Dar es Salaam city whereby micro traders had been affected by reallocations and harassment more than in the regional towns. Example in Ilala alone, 40,000 prosecutions were issued by the local authority against micro traders including women micro entrepreneurs in the six months starting February 2007, in an estimated population of 250,000 micro traders.

Another contention for the current survey analysis is from Mbwambo (2003). According to this study many people in micro trade get losses because of unrests between them and city authorities. The study found that 52.7 percent of micro traders who filled the questionnaire were reported to have been harassed by city authority and their properties destroyed or confiscated.

According to Olomi (2003), there are a number of constraints which hinder the development of women micro entrepreneurs. These discourage and complicate entry, survival and development of Women Micro Enterprises. They can be summarized as follows: The key issues inhibiting women entrepreneurs include:

\section{Macro and Micro level factors:}

Macro level are: cultural environment that makes it more difficult for women to start and run enterprises due to their traditional reproductive roles, laws and regulations (including licensing procedures) and taxes which are out of reach of Micro Entrepreneurs; Corruption and bureaucracy.

Micro level are: Capacity problems on the part of women entrepreneurs in terms of general level of education, technical and business management skills including the sophistication to work with financial institutions attitudes, in terms of interest and commitment in the activity and the career and motivation to develop the activity among those who start business as a result of economic necessity.

Critical barriers for women entrepreneurs are different according to the segment in which they are. For those who are running only informal micro enterprises (and this is where most women are concentrated), their main challenges are dealing with costly and complicated formalization procedures (if they wish to formalize), harassment due to operating in locations and premises that are not approved for business and affording the time required to attend training supported by donors and NGOs. For those who are running formal micro enterprises, the unique critical challenges are dealing with high and multiple taxes, complex tax compliance procedures and access to finance.

Another challenge is the HIV/AIDS pandemic which is a major threat to all economic activities, including MEs. The disease has been claiming the lives of many entrepreneurs as well as their employees. It is crippling women micro entrepreneurs who as women their duty is to care for the sick or orphaned relatives. The existing AIDS awareness campaigns are targeted mainly to the general public and are not specifically targeting business people who are more vulnerable. 


\section{Meso-level factors:}

Meso level includes: Limited access to support services, including credit, technical and management training, advise and marketing, Limited organization and management capacity among women's advocacy organizations.

\section{Challenges Faced by Ilala Municipality in addressing micro business operations}

In spite of various strategies employed by Ilala municipality to ensure all micro traders in the city abided by the reallocation policy, the eviction operation exercise has encountered numerous obstacles. Apart from budget deficit in the Municipal, other barriers cover areas like frequent violence and unavailability of open spaces to establish new markets and corruption. 80 per cent of the officials who responded to the study cited frequent violence as a leading challenge toward achieving their operation goals. Generally, the officials observed that since the establishment of the reallocation policy, micro traders have been organizing themselves into groups of ten to twelve in order to resist from being caught by city authorities. Traditional weapons like stones, sticks and other locally made are being used by micro traders to attack city authorities.

There is generally lack of cooperation from micro traders. About 70 percent of interviewed officials mentioned this behaviour of micro traders as among the challenges. They cited micro traders' behaviour like making temporal retreat (lasting from few hours up to many months) and bouncing back to business once the pressure is over. They exemplified most critical area as Mchikichini near Karume stadium in Ilala. Other micro entrepreneurs have abandoned the new business places allocated to them, like Tazara Market, and are going back to their former unauthorized trading areas during nights and weekends.

The interview further showed that all of the municipal officials thought that budget deficit was also a challenge to achieve their aims of putting all micro entrepreneurs in proper place. As the municipal planner commented:

The central government has formulated a policy but a consideration on implementation resources is left to the implementers like municipals...the municipal is facing financial challenges since the central government removed nuisance taxes. This has eliminated 60 percent of the funding raised in the municipals (15/06/2010).

The increase in number of micro entrepreneurs in Ilala Municipal also was another challenge. Officials pointed out that the number of youths joining micro trade in Dar es Salaam municipalities (Ilala, Kinondoni and Temeke) has increased significantly to about 700,000. They cited opportunities in this trade and increased poverty level in rural areas as pushing factors. Population increase in municipals has lead to the establishment of poor settlement areas and hence the lack of open space for establishing new market areas in the city. About 60 per cent of municipal officials thought that this challenge was inherited since all previous governments (first, second and third phase) failed to establish a sustainable city land use plan. From interviewing municipal officials it is shown that two major setbacks threatening the achievement of reallocation policy objectives were violence and lack of cooperation from micro entrepreneurs. This was because the municipal council have failed to establish proper and adequate space for micro entrepreneurs. Since most of the micro entrepreneurs perceived 
micro trade as way of life and most of them were married (about 50 percent) with dependants at home, they did not have other option to make their family survive but only struggling with city authority.

Corruption among municipal officials and militias is another challenge to implement the policies. 80 per cent of the officials who responded to the study cited corruption as a major challenge. For example: The new market constructed special for machingas has been reallocated to politicians and many government officials; first markets around Benjamin Mkapa High School, and now the Machinga Complex at Karume stadium.

\section{Policy Implications and Recommendations}

First, the current demand for micro trading space is high and competitive, while there are restrictive conditions imposed on few areas where micro trading activities are allowed. The developed places are too ill-equipped or placed to attract the existing cadre of micro entrepreneurs as well as new entrants into the trade.

Second, the present set up of business trading discriminates against very low capital micro entrepreneurs who resort to unhealthy handling of trading including locating themselves anywhere without any official allocation.

Third, the existing method of handling micro traders is too coercive and costful to both entrepreneurs and municipal authorities, thereby defeating the very essence for which the city officials set out to achieve.

Fourth, there exist little or lack of cooperation and coordination from various stakeholders, including the central government and micro entrepreneurs themselves, in finding out permanent and sustainable solution to the reallocation policies that over time have adversely affected the micro trading business sector in the country.

From the foregoing, the following recommendations emerging from study findings and implications are put forward as hereunder.

\section{To Policy formulators/ urban planners}

Land use planning and commercial authorities should reconsider providing new land use and commercial trading policy that will cater for beneficiaries of all categories, including very low capital women micro entrepreneurs.

The central government, local government and the large business community should recognize the micro trading informal business sector as an important partner in issues of employment, revenue generation and customer's friendliness. Therefore a business and policy friendly communication system should be put in place towards a fair trading partnership. 


\section{REFERENCES}

Chijoriga,M. \& D. Cassimon (1999). Micro enterprises Financing: Is there a Best Model?, in Rutashobya L.K. and Olomi, D.R. (eds), African Entrepreneurship and Small Business Development, Dar es Salaam, DUP (1996) Ltd.

Coleman,S (2002). Constraints facedby Women Small Business Owners. Evidence from the Data, Journal of Development Entrepreneurship 7(2) 151-174.

Koda, B. \& Omari, C. K. (1991). 'Crisis in Household economy; Women's strategies in Dar es Salaam.' In Mohamed suliman (ed) Alternatives strategies for Africa: Volume 11:10. London: IFAA.

Lutege, P. \& Wagner, S. (2002). Women in Business: A Study on Women Enterprise Development in Four Districts in Tanzania Submitted for FAIDA-SEP.

Lwihula, (1999), cited in R. D. Olomi, "Entrepreneurship and Small Business, a Tanzanian

Perspective," University of Dar es Salaam Entrepreneurship Centre (UDEC), 2003.

Mbilinyi, M. (ed) (2000). Gender Patterns in Micro Enterprises of Tanzania. Rome:

AIDOS Via der Giubbouare, Italy.

Nchimbi (1999). Cited in R. D. Olomi, "Entrepreneurship and Small Business, a

Tanzanian Perspective." University of Dar es Salaam Entrepreneurship Centre (UDEC), 2003.

Nchimbi, M.I. (2002). Gender and Entrepreneurship in Tanzania: A Comperative

Analysis of Male-Female's Start-Up Motivation, Individual chacteristics and Perceptions of Business Sucess, PhD Thesis, University of Dar es Salaam.

OECD (2004). Women's Entrepreneurship: Issues And Policies 2nd OECD Conference

Of Ministers Responsible For Small And Medium-Sized

Enterprises (SMES) Promoting Entrepreneurship And Innovative SMES In A Global Economy: Towards A More Responsible And Inclusive Globalization Istanbul, Turkey 3-5 June 2004. Found online at, http://www.oecd.org/dataoecd/6/13/31919215.pdf. Accessed on $\underline{13 / 3 / 2010 .}$.

Olomi R.D. (2001). Entrepreneurial Motivation in Developing Country Context:

Incidence, Antecedence and Consequences of Growth-seeking Behaviour Among Tanzania Owner-Managers. A PhD Thesis, University of Dar es Salaam, Tanzania.

Olomi R.D. (2003). Entrepreneurship and Small Business, a Tanzanian Perspective," University of Dar es Salaam Entrepreneurship Centre (UDEC).

Olomi, R.D \& Sinyamule, S.R. (2007). "Entrepreneurial Inclinations of Vocational

Education students: A comparative study of male and female trainees in Iringa region, Tanzania Uongozi Journal of management Tanzania: Entry and Performance 